\title{
PENGARUH KEMANDIRIAN, GAYA BELAJAR DAN LINGKUNGAN BELAJAR TERHADAP HASIL BELAJAR AKUNTANSI SISWA KELAS X PROGRAM KEAHLIAN AKUNTANSI SMK PGRI 3 SIDOARJO
}

\author{
Devi Kartika Saragih, SMK PGRI 3 Sidoarjo \\ devichartika@ymail.com
}

\begin{abstract}
ABSTRAK
Penelitian ini bertujuan untuk mengetahui pengaruh kemandirian, gaya belaja, lingkungan belajar, kemandirian, gaya belajar dan lingkungan belajar terhadap hasil belajar siswa kelas X Akuntansi SMK PGRI 3 Sidoarjo dengan sampel sebanyak 107 siswa. Jenis penelitian ini adalah penelitian korelasi dengan pendekatan kuantitatif. Data dianalisis dengan menggunakan analisis regresi. Berdasarkan analisis data dan hasil penelitian ini menunjukkan adanya pengaruh signifikan antara kemandirian belajar terhadap hasil belajar, ada pengaruh signifikan antara gaya belajar siswa terhadap hasil belajar siswa. ada pengaruh signifikan antara lingkungan belajar siswa terhadap hasil belajar, dan ada pengaruh secara simultan antara kemandirian, gaya belajar dan lingkungan belajar terhadap hasil belajar siswa kelas X Akuntansi SMK PGRI 3 Sidoarjo
\end{abstract}

Kata Kunci: Kemandirian, Gaya Belajar, Lingkungan Belajar dan Hasil Belajar

\section{ABSTRACT}

This study aimed to determine the effect of self-reliance, learning style and learning enviroment for accounting achievement in grade X of SMK PGRI 3 Sidoarjo for academic years 2013/2014. Sample was 107 students selected by using simple random sampling technique. Data were collected by questionnaires and documentation method. The method of analysis in this study was a correlation research with quantitative approach analysis, multiple linear regressions. According to analysys and results showed there is a significant effect between : self-reliance to the student learning results, there is a significant effect between students learning style to the student learning results, there is a significant effect between learning environment to the student learning results, and there is a simultaneous effect between self reliance learning style and learning environment to the learning results on $X$ grade of accounting students in SMK PGRI 3 Sidoarjo no particial effect on self-reliance to achievement of accounting, there is no particial effect on learning style to achievement of accounting, there is no particial effect on learning enviromentto achievement of accounting, and there are no simultaneous effect on self-reliance, learning style and learning enviroment on the learning achievement of accounting.

Keywords: self-reliance, learning style, learning enviroment and learning achievement 


\section{PENDAHULUAN}

Akuntansi merupakan mata pelajaran yang unik. Hal tersebutdikarenakan akuntansi termasuk dalam kelompok ilmu sosial yang didalamnya terdapat seni menganalisis, mengelompokan, mencatat dan melaporkan data akuntansi menjadi laporan keuangan. Selain itu, matapelajaran akuntansi menuntut kemampuan siswa yang lebih untukmemahami konsep-konsep dasar, prinsip, dan prosedur akuntansidengan baik dan benar.

Hasil belajar akuntansi merupakan salah satu indikator untuk mengetahui keberhasilan belajar pada mata pelajaran akuntansi. Dengan hasil belajar yang baik diharapkan mampu menggambarkan kualitas pendidikan yang baik. Dalam usaha untuk mencapai hasil belajar yang optimal dipengaruhi oleh faktor internal dan faktor eksternal. Menurut (Slameto, 2010) faktor-faktor yang mempengaruhi prestasi belajar ada dua antara lain faktor internal dan faktor eksternal. Faktor internal yaitu faktor yang berasal dari dalam diri. Faktor internal terdiri atas: Kesehatan, Intelegensi dan Bakat, Minat dan Motivasi, dan Cara Belajar. Faktor yang kedua adalah Faktor Eksternal yaitu faktor yang berasal dari luar diri. Faktor eksternal terdiri atas Keluarga, Sekolah, Masyarakat dan Lingkungan sekitar

Banyaknya bagian bagian yang harus dijelaskan oleh guru pada pelajaran akuntansi menuntun siswa harus bisa belajar sendiri tanpa harus selalu diarahkan oleh gurusehingga mampu meningkatkan hasil belajarnya. Oleh karena itu untuk mencapai hasil belajar yang maksimal diduga perlu dikembangkan kemandirian belajar. Menurut Tirtarahardja dan La Sulo (2005) menyatakan bahwa kemandirian belajar adalah aktivitas belajar yang berlangsungnya lebih didorong oleh kemauan sendiri, pilihan sendiri dan tanggung jawab sendiri. Kemandirian akan mendorong manusia untuk berprestasi dan berkreasi.Siswa yang mempunyai sikap mandiri akan lebih berani memutuskan hal-hal yang berkenaan dengan dirinya bebas dari pengaruh orang lain, mampu berinisiatif dan mengembangkan kreatifitas serta merangsang untuk berprestasi lebih baik.

Dengan kemandirian belajar, siswa akan belajar menguasai materi pelajaran dengan usaha sendiri tanpa adanya guru atau disuruh orang tua, sehingga siswa akan cenderung positif dan aktif dalam belajar.Mujiman, Haris (2007) menambahkan bahwa kemandirian belajar sebagai sifat serta kemampuan yang dimiliki siswa untuk melakukan kegiatan belajar aktif, yang didorong oleh motif untuk menguasai sesuatu kompetensi yang telah dimiliki. Melalui pengembangan sikap mandiri dalam belajar, maka siswa dapat mendiagnosa kesulitan belajarnya dan mencari solusi yang tepat untuk memecahkan kesulitan tersebut. Hal ini tentu akan menjadi pengaruh yang positif bagi siswa itu sendiri dalam hal penguasaan konsep belajar.

Selain kemandirian belajar, faktor lain yang diduga mempengaruhi hasil belajar akuntansi adalah gaya belajar siswa. Menurut Deporter dan Hernacki (2001), individu dalam belajar memiliki berbagai macam cara, ada yang belajar dengan cara mendengarkan, ada yang belajar dengan membaca, serta belajar dengan cara menemukan. Dalam pembelajaran Akuntansi secara umum siswa SMK lebih cenderung atau dominan menggunakan gaya belajar kinestetik dalam kegiatan belajar dikelas. Gaya belajar kinestetik memiliki peran penting bagi hasil belajar siswa. 
Dryden dan Jeannette (2002) menyatakan gaya belajar kinestetik adalah belajar yang melalui aktivitas fisik dan keterlibatan langsung. Proses pembelajaran yang tidak bisa berdiam diri karena ingin melibatkan fisiknya untuk terlibat langsung. Siswa yang memiliki gaya belajar kinestetik selalu ingin memperagakan secara langsung tanpa membaca instruksi yang disediakan. Siswa suka menangani, bergerak, menyentuh dan merasakan atau mengalami sendiri . Gaya belajar kinestetik memiliki peran penting bagi hasil belajar siswa. Juga dapat ditunjukkan melalui hasil penelitian sebelumnya yang dilakukan oleh Bisri dan Pudjo (2012) menyatakan bahwa siswa yang memiliki kecenderungan gaya belajar kinestetik memperoleh hasil belajar yang lebih tinggi artinya gaya belajar kinestetik memberikan pengaruh terhadap hasil belajar akuntansi siswa pada siswa SMK.

Selain faktor kemandirian belajar dan gaya belajar, fakor lain yang diduga mempengaruhi hasil belajar akuntansi adalah lingkungan belajar. Secara umum pelajaran akuntansi lebih dominan menggunakan praktik, maka dibutuhkan lingkungan fisik sekolah yang mendukung seperti kelengkapan fasilitas belajar yang memadai dari sekolah. Kondisi lingkungan sekolah ini memiliki peran penting dalam menentukan kelancaran proses pembelajaran. Dalam proses belajar mengajar lingkungan sekolah merupakan sumber belajar yang berpengaruh pada proses pembelajaran yang berlangsung didalamnya.

Menurut Dalyono (2009),Sekolah merupakan satu faktor yang turut mempengaruhi pertumbuhan dan perkembangan anak terutama untuk kecerdasannya, Lingkungan sekolah mempengaruhi tingkat keberhasilan belajar seperti : kualitas guru, metode mengajarnya, kesesuaian kurikulum dengan kemampuan anak, keadaan fasilitas/perlengkapan sekolah, keadaan ruangan, jumlah murid per kelas, pelaksanaan tata tertib dan seterusnya yang semua itu turut mempengaruhi keberhasilan belajar. Menurut Slameto (2010), Lingkungan sekolah siswa meliputi lingkungan fisik terdiri dari tempat belajar, alat-alat belajar belajar akuntansi, sumber belajar akuntansi, media pembelajaran dan ruangan laboratorium. Mengacu pada teori dan ciri-ciri lingkungan belajar disekolah,. Hamalik (2005) juga menyatakan bahwa Sekolah dapat mengembangkan dan meningkatkan pola pikir anak karena disekolah mereka dapat belajar bermacammacam ilmu pengetahuan.

Lingkungan sekolah memiliki peran penting bagi hasil belajar siswa. dapat ditunjukkan melalui hasil penelitian sebelumnya yang dilakukan oleh Sagoro (2012) yang menyatakan bahwa lingkungan sekolah memberi pengaruh yang positif dan signifikan terhadap hasil belajar akuntansi. Jika kondisi lingkungan sekolah sangat mendukung, maka siswa akan lebih bersemangat dalam proses pembelajaran.

Fenomena yang terjadi di kelas X akuntansi SMK PGRI 3 Sidoarjo saat ini menunjukkan bahwa hasil belajar akuntansi siswa masih rendah hal ini dapat dilihat dari hasil ulangan harian siswa semester 1 masih ada sekitar 42,25\% dari total siswa nilai ulangan hariannya belum memenuhi standar ketuntasan yang ditetapkan sekolah yaitu nilai 76, Sehingga siswa-siswa tersebut masih harus mengikuti ulangan perbaikan atau remedial. Berdasarkan observasi singkat peneliti, fenomena yang terjadi adalah kemandirian belajar siswa kelas X SMK PGRI 3 Sidoarjo relatif masih kurang optimal, hal itu tercermin dari masih adanya siswa yang sering mencontek saat mengerjakan tugas ataupun pada saat ulangan 
berlangsung. Bahkan sering dijumpai bahwa siswa mengerjakan tugas pada pagi hari sebelum jam pelajaran dimulai dengan mengandalkan teman yang rajin atau pandai. Ketergantungan pada siswa lain yang memiliki kemampuan lebih dalam mengerjakan tugas atau pekerjaan rumah seakan telah menjadi suatu kebiasaan, bahkan pada saat ulangan pun mereka cenderung mengandalkan temannya karena tidak percaya dengan kemampuan yang dimilikinya sendiri.

Begitu juga dengan cara belajarnya, peneliti mendapati siswa memiliki cara yang berbeda-beda dalam belajar, Berdasarkan hasil wawancara dengan siswa yang dilakukan di kelas $\mathrm{X}$ program keahlian akuntansi SMK PGRI 3 Sidoarjo menunjukan siswa dalam belajar akuntansi cenderung lebih tertarik ketika dihadapkan pada soal soal latihan, langsung kepada praktik, bukan sekedar pemahaman terhadap teori akuntansi yang diberikan guru saja. Oleh karena pelajaran akuntansi lebih cenderung atau dominan langsung dengan praktik, maka harus didukung juga dengan lingkungan sekolah yang memadai seperti fasilitas sekolah yang lengkap, metode mengajar guru yang bervariasi, relasi guru dengan siswa dan relasi siswa dengan siswa. Berdasarkan observasi singkat yang dilakukan peneliti di SMK PGRI 3 Sidoarjo, fasilitas belajar siswa belum dimanfaatkan semaksimal mungkin seperti alat alat belajar akuntansi, perpustakaan, laboratorim komputer dan media pembelajaran.

Berdasarkan beberapa penelitian terdahulu, terdapat beberapa faktor yang dapat mempengaruhi hasil belajar diantaranya kemandirian, gaya belajar dan lingkungan belajar. Ke tiga faktor ini menjadi penting diteliti kembali karena dalam penelitian terdahulu terbukti ke tiganya faktor ini secara signifikan berpengaruh pada hasil belajar

Berdasarkan latar belakang masalah dan rumusan masalah yang ada, maka diduga ada pengaruh kemandirian, gaya dan lingkungan belajar terhadap hasil belajar akuntansi siswa kelas $\mathrm{X}$ program keahlian akuntansi SMK PGRI 3 Sidoarjo

\section{METODE PENELITIAN}

Pendekatan dalam penelitian ini adalah pendekatan kuantitatif. Penelitian ini dirancang dengan menggunakan penelitian eksplanatory. Terdapat tiga variabel bebas dalam penelitian ini yaitu kemandirian belajar (X1), gaya belajar (X2) dan lingkungan belajar (X3) dan satu variabel terkait yaitu hasil belajar (Y). Ketiga variabel bebas (X1, X2 dan X3) akan dianalisis pengaruh masing masing variabel bebas tersebut terhadap variabel terikat (Y). Jadi dalam penelitian ini akan dilakukan analisis regresi berganda (multiple linear regression).

Analisis tersebut kemudian dilanjutkan dengan menganalisis ketiga variabel bebas tersebut secara bersama sama. Adapun indikator yang digunakan dalam kemandirian belajar mengacu pada ciri ciri kemandirian belajar menurut Hidayati dan Listyani (2010) yang terdiri dari enam indikator antara lain :

a) Berprilaku berdasarkan inisiatif sendiri

Dalam penelitian ini, indikator berprilaku berdasarkan inisiatif sendiri yang dimaksud seperti siswa belajar atas kemauannya sendiri dan siswa mengerjakan soal-soal latihan meskipun bukan sebagai tugas sekolah, serta siswa bertindak secara sadar atas kehendak mereka sendiri

b) Berprilaku displin 
Indikator berprilaku disiplin yang dimaksud dalam penelitian ini adalah siswa berusaha hadir sekolah tepat waktu dan siswa senantiasa mengumpulkan tugas-tugas sekolah tepat waktu serta siswa mengevaluasi hasil belajarnya

c) Melakukan kontrol diri

Indikator melakukan kontrol diri yang dimaksud dalam penelitian ini seperti siswa mencermati kenaikkan dan penurunan hasil belajarnya, dan siswa merencanakan sendiri kegiatan belajarnya.

d) Ketidaktergantungan terhadap orang lain

Dalam penelitian ini, indikator ketidaktergantungan terhadap orang lain yang dimaksud seperti siswa berpendapat secara sadar atas keinginannya sendiri, siswa memilih sendiri strategi belajarnya dan dalam menyelesaikan tugastugas sekolah, siswa menyelesaikannya sesuai dengan kemampuannya sendiri.

e) Memiliki kepercayaan diri

Dalam penelitian ini, indikator memiliki kepercayaan diri yang dimaksud seperti siswa memiliki keyakinan dapat mencapai tujuan belajarnya,dan siswa juga memiliki keyakinan mampu mengatasi masalah atau hambatan yang siswa hadapi dalam kegiatan belajarnya

f) Memiliki rasa tanggung jawab

Indikator memiliki rasa tanggung jawab yang dimaksud dalam penelitian ini seperti siswa memacu diri untuk terus bersemangat dalam belajar, dan siswa berusaha melaksanakan rencana kegiatan belajarnya sebaik mungkin serta siswa yakin bahwa aktifitas belajar siswa pada akhirnya berdampak pada dirinya sendiri

Berdasarkan hasil penelitian pada variabel kemandirian belajar (X1) dapat disimpulkan bahwa dominan atau nilai tertinggi jawaban responden, terdapat pada indikator berperilaku disiplin, responden menyatakan bahwa sebagian besar siswa sudah berusaha hadir sekolah tepat waktu, sebagian besar siswa sudah mengumpulkan tugas dengan waktu yang telah ditentukan oleh guru,dan dalam hal kedisplinan rutinitas belajar sebagian siswa menyatakan bahwa mereka mengevaluasi hasil belajarnya. Hal tersebut memberikan gambaran bahwa responden sudah memiliki sikap kedisiplinan.

Sedangkan jawaban minimal atau terendah rsponden berdasarkan hasil penelitian terdapat pada indikator berperilaku berdasarkan inisiatif sendiri, responden menyatakan bahwa hanya sebagian mereka yang kadang-kadang belajar atas kemauan mereka sendiri, belum sebagian besar responden yang belajar atas kemauannya sendiri. responden juga menyatakan bahwa hanya sebagian dari mereka yang kadang-kadang mengerjakan sosal-soal latihan, meskipunbukan sebagai tugas sekolah. Dan responden juga menyatakan bahwa mereka bertindak secara sadar atas kehendaknya sendiri.

Begitu juga dengan gaya belajar, indikator yang digunakan dalam penelitian ini mengacu pada ciri-ciri gaya belalajar menurut Deporter dan Hernacki (2002), indikator gaya belajar tersebut antara lain :

a) Belajar dengan aktivitas fisik

Dalam penelitian ini, indikator belajar dengan aktivitas fisik yang dimaksud adalah Siswa yang mempunyai gaya belajar kinestetik belajar melalui bergerak, menyentuh, dan melakukan. Mereka tidak tahan untuk duduk 
berlama-lama mendengarkan pelajaran dan merasa bisa belajar lebih baik jika prosesnya disertai kegiatan fisik.

b) Peka terhadap ekspresi dan bahasa tubuh

Siswa dengan gaya belajar kinestetik mudah menghafal dengan cara melihat gerakan tubuh/fisik sambil berjalan mempraktikkan.

c) Berorientasi pada fisik dan banyak bergerak

Siswa kinestetik biasanya mempunyai perkembangan awal otot-otot yang besar, menggunakan jari sebagai penunjuk ketika membaca, banyak menggunakan isyarat tubuh, suka praktik.

d) Suka coba-coba dan kurang rapi

Dalam penelitian ini, indikator suka coba-coba dan kurang rapi yang dimaksud adalah belajar melalui memanipulasi dan praktik, kemungkinan tulisannya jelek.

e) Lemah dalam aktivitas verbal

Indikator lemah dalam aktivitas verbal yang dimaksud dalam penelitian ini adalah Cenderung berbicara dengan perlahan, sehingga perlu berdiri dekat ketika berbicara dengan orang lain.

Sesuai dengan hasil angket responden dalam penelitian pada variabel gaya belajar (X2), jawaban dominan atau yang tertinggi terdapat pada indikator belajar dengan aktivitas fisik. Indikator belajar dengan aktivitas fisik seperti siswa lebih memahami pelajaran akuntansi ketika praktik dari pada teori di kelas artinya dalam kegiatan belajar siswa lebih cepat mengerti pembelajaran yang mereka terima dari guru dengan cara praktik, siswa langsung terlibat dalam pembelajaran. Sedangkan jawaban terendah ada pada indikator peka terhadap ekspresi dan bahasa tubuh. Indikator peka terhadap ekspresi dan bahasa tubuh seperti siswa kurang peka terhadap perubahan ekspresi lawan bicara ketika berbicara.

Sedangkan lingkungan belajar yang digunakan dalam penelitian ini, mengacu pada ciri ciri lingkungan belajar menurut Slameto (2010) dan Dalyono (2009) seperti yang diuraikan di atas maka diketahui indikator-indikator lingkungan belajar antara lain:

a) Keadaan sekolah tempat belajar

Dalam penelitian ini, indikator keadaan sekolah tempat belajar yang dimaksud adalah lingkungan sekitar sekolah yang nyaman seperti kelas yang bersih dan rapi

b) Metode mengajar guru

Metode mengajar guru yang dimaksud disini adalah guru menggunakan metode mengajar yang bervariasi dalam mengajar seperti dalam mengajar guru melakukan tanya jawab dan setiap selesai pelajaran guru memberikan tugas rumah, serta guru sering melakukan praktik dalam pembelajaran akuntansi

c) Hubungan siswa, guru dan staf/ karyawan sekolah

Dalam penelitian ini, hubungan siswa,guru dan staf/karyawan sekolah yang dimaksud seperti ketika siswa mengalami kesulitan dalam mengerjakan PR akuntansi teman-teman dilingkungan sekolah membantu, antara siswa dan guru maupun staf/karyawan saling bertegur sapa ketika dilingkungan sekolah dan ketika siswa mengalami kesulitan dalam belajar, siswa membentuk kelompok belajar untuk memecahkan persoalan tersebut 
d) Tata tertib sekolah

Indikator tata tertib sekolah yang dimaksud dalam penelitian ini seperti pelanggaran tata tertib sekolah akan dikenakan sanksi atau hukuman sehingga tata tertib sekolah selalu ditaati oleh semua siswa, guru dan staf/karyawan

e) Keadaan gedung sekolah dan fasilitas sekolah

Dalam penelitian ini, indikator keadaan gedung sekolah dan fasilitas sekolah yang dimaksud seperti sarana pendukung pembelajaran disetiap kelas disediakan sekolah dengan baik, ruang laboratorium komputer di manfaatkan guru dalam pembelajaran akuntansi serta media dalam pembelajaran disediakan dengan baik dan lengkap

Sesuai dengan hasil angket responden dalam penelitian pada variabel lingkungan belajar (X3), jawaban dominan atau yang tertinggi terdapat pada indikator tata tertib sekolah yang menunjukkan bahwa lingkungan sekolah sudah ditaati oleh semua warga sekolah dan pelanggaran terhadap tata tertib sekolah akan dikenakan sanksi atau hukuman. Hal ini menunjukkan bahwa tata tertib di sekolah sudah ditaati. Sedangkan sesuai jawaban yang terendah dari hasil angket responden dalam penelitian terdapat pada indikator metode mengajar guru yang menunjukkan bahwa guru kurang menggunakan metode yang bervariasi dalam melaksanakan pembelajaran khususnya mata pelajaran akuntansi dan guru kurang memberikan praktik dalam pembelajaran akuntansi.

Populasi dalam penelitian ini adalah siswa kelas X Akuntansi SMK PGRI 3 Sidoarjo tahun pelajaran 2013/2014 yaitu sebanyak 147 siswa. Sampel penelitian sebanyak 107 siswa ditetapkan dengan teknik proporsional. Data dikumpulkan dengan penyebaran kuisioner dan dokumentasi. Kuisioner disusun berdasarkan variabel penelitian dan indikator penelitian dengan skala pengukuran instrumen menggunakan skala linkert. Uji asumsi klasik yang dilakukan dalam penelitian ini adalah uji linieritas, uji multikolinieritas, uji normalitas dan uji heteroskedastisitas.

Teknik analisis menggunakan analisis uji statistik $F$ dan uji t. Uji $F$ digunakan untuk menguji signifikansi pengaruh variabel kemandirian, gaya belajar dan lingkungan belajar pada hasil belajar akuntansi. Uji t digunakan untuk menguji signifikansi pengaruh variabel kemandirian pada hasil belajar akuntansi, pengaruh gaya belajar pada hasil belajar akuntansi dan pengaruh lingkungan belajar pada hasil belajar akuntansi.

\section{HASIL PENELITIAN DAN PEMBAHASAN}

\section{Hasil Penelitian}

Hasil uji linieritas antara variabel kemandirian belajar dengan hasil belajar, tampak bahwa nilai $\mathrm{F}$ (Deviation from linearity) yang dihasilkan sebesar 0,815 dengan nilai sgnifikan lebih besar 5\% yaitu sebesar 0,716. Dengan tingkat signifikan yang melebihi $5 \%$ maka hubungan antara kemandirian belajar $\left(\mathrm{X}_{1}\right)$ dengan hasil belajar (Y) dinyatakan linier. Hasil uji linieritas antara variabel gaya belajar dengan hasil belajar, tampak bahwa nilai $\mathrm{F}$ (Deviation from linearity) yang dihasilkan sebesar 0,854 dengan nilai signifikan lebih besar 5\% yaitu sebesar 0,656. Dengan tingkat signifikan yang melebihi 5\% maka hubungan antara gaya belajar $\left(\mathrm{X}_{2}\right)$ dengan hasil belajar $(\mathrm{Y})$ dinyatakan linier. Hasil uji linieritas antara 
variabel lingkungan belajar dengan hasil belajar, tampak bahwa nilai $\mathrm{F}$ (Deviation from linearity) yang dihasilkan sebesar 0,989 dengan nilai signifikan lebih besar $5 \%$ yaitu sebesar 0,488. Dengan tingkat signifikan yang melebihi 5\% maka hubungan antara lingkungan belajar $\left(\mathrm{X}_{3}\right)$ dengan hasil belajar $(\mathrm{Y})$ dinyatakan linier.

Dari hasil uji multikolinieritas dapat disimpulkan bahwa variabel kemandirian belajar $\left(\mathrm{X}_{1}\right)$ memiliki nilai VIF 1,494, Variabel gaya belajar $\left(\mathrm{X}_{2}\right)$ memiliki nilai VIF 1,467 dan Lingkungan belajar $\left(\mathrm{X}_{3}\right)$ memiliki nilai VIF 1,690 yang berarti kurang dari 10, maka dapat dikatakan bahwa antara variabel bebas tidak terjadi Multikolinieritas.

Dari hasil uji normalitas dapat disimpulkan bahwa nilai KolmogorovSmirnov yang dihasilkan dari variabel bebas dan variabel terikat adalah sebesar 0,716 dengan tingkat signifikan sebesar 0,684 . Tingkat yang dihasilkan tersebut lebih dari 5\% yang berarti residual mengikuti distribusi normal, sehingga variabel kemandirian belajar $\left(\mathrm{X}_{1}\right)$, gaya belajar $\left(\mathrm{X}_{2}\right)$, lingkungan belajar $\left(\mathrm{X}_{3}\right)$ dan hasil belajar (Y) dengan sendirinya berdistrbusi normal

Dari hasil uji heteroskedastisitas dapat disimpulkan bahwa tingkat signifikan yang dihasilkan melebihi $5 \%$ yaitu 0,795 pada variabel kemandirian belajar $\left(\mathrm{X}_{1}\right), 0,710$, pada variabel gaya belajar $\left(\mathrm{X}_{2}\right)$ dan 0,768 dan pada variabel lingkungan belajar $\left(\mathrm{X}_{3}\right)$ maka dapat dikatakan bahwa antara variabel bebas dengan residual tidak terjadi heteroskedastisitas.

Model regresi yang diperoleh berdasarkan hasil penelitian, dapat dituliskan dalam bentuk persamaan regresi adalah sebagai berikut : $\mathrm{Y}=8,388+0,468 \mathrm{X}_{1}+$ $0,458 X_{2}+0,315 X_{3}$. Dari persamaan tersebut, ke tiga variabel bebas memiliki koefisien regresi dengan arah positif. Hal ini berarti bahwa semakin tinggi kemandirian, gaya belajar dan lingkungan belajar akan meningkatkan hasil belajar akuntansi siwa. Hasil uji $\mathrm{F}$ berdasarkan uji ANOVA atau uji statistik F, model menunjukkan nilai $\mathrm{F}$ sebesar 31,940 dengan probabilitas 0,00 sebesar kurang dari $5 \%$, hal ini berarti bahwa hasil belajar dapat dijelaskan oleh variabel kemandirian, gaya belajar dan lingkungan belajar secara bersama-sama atau dengan kata lain semua variabel bebas secara bersama-sama merupakan penjelas yang signifikan pada variabel terikat.

Koefisien determinasi (R-square) yang dihasilkan dalam penelitian ini sebesar 0,482 menunjukkan kemandirian (X1), gaya belajar (X2), dan lingkungan belajar (X3) berpengaruh pada hasil belajar siswa (Y) sebesar 48,2\% sedangkan sisanya $51,8 \%$ dipengaruhi oleh faktor lain yang tidak dibahas pada penelitian ini.

Lebih lanjut uji parsial menunjukkan semua variabel mempunyai pengaruh yang signifikan. Uji parsial menunjukkan nilai t-hitung pada variabel kemandirian (X1) sebesar 4,186 dengan tingkat signifikan kurang dari 5\% yaitu 0,000, t-hitung pada variabel gaya belajar (X2) sebesar 3,255 dengan tingkat signifikan kurang dari 5\% yaitu 0,002, t-hitung pada variabel lingkungan belajar (X3) sebesar 2,200 dengan tingkat signifikan kurang dari $5 \%$ yaitu 0,030 . Dengan tingkat signifikan yang kurang dari $5 \%$ berarti menunjukkan bahwa kemandirian, gaya belajar dan lingkungan belajar secara parsial berpengaruh signifikan pada hasil belajar (Y). 


\section{Pembahasan}

\section{Pengaruh Kemandirian Pada Hasil Belajar}

Berdasarkan penelitian mengenai pengaruh kemandirian pada hasil belajar menunjukkan bahwa kemandirian berpengaruh signifikan positif pada hasil belajar. Hal ini ditunjukkan melalui hasil persamaan regresi linier berganda diperoleh nilai t-hitung pada variabel kemandirian (X1) sebesar 4,186 dengan tingkat signifikan kurang dari 5\% yaitu 0,000, artinya semakin tinggi kemandirian belajar siswa maka semakin tinggi hasil belajar siswa.

Koefisien regresi pada variabel kemandirian sebesar 0,468 menunjukkan bahwa kemandirian memiliki pola hubungan yang searah dengan hasil belajar yaitu semakin tinggi kemandirian belajar maka semakin tinggi hasil belajar siswa

Hasil penelitian ini sesuai dengan teori yang dinyatakan oleh Tirtahardja dan La Sulo (2005) bahwa "kemandirian dalam belajar adalah aktivitas belajar yang berlangsungnya didorong oleh kemauan sendiri, pilihan sendiri dan tanggung jawab sendiri". Dorongan dari internal individu memiliki kunci pokok dalam kegiatan belajar anak. Perolehan hasil belajar yang didapat anak, baik keterampilan maupun kompetensi tertentu akan mampu dicapai jika dialami sendiri dalam proses prolehan hasil belajar tersebut.

Menurut Mujiman (2007) "kemandirian belajar dapat diartikan sebagai sifat serta kemampuan yang dimiliki siswa untuk melakukan kegiatan belajar aktif, yang didorong oleh motif untuk menguasai sesuatu kompetensi yang telah dimiliki". Pendapat lain dikemukakan oleh Thoa (1996) menyatakan bahwa "kemandirian adalah aktivitas belajar yang didorong oleh kemauan sendiri, pilihan sendiri dan tanggung jawab sendiri tanpa bantuan orang lain serta mampu mempertanggung jawabkannya"

Hasil penelitian ini juga didukung oleh kajian empirik dari penelitian terdahulu yaitu Sagoro (2012) yang menunjukkan bahwa kemandirian belajar, metode Pembelajaran dan lingkungan belajar berpengaruh secara positif dan signifikan terhadap prestasi belajar akuntansi siswa. Hal yang sama juga diungkapkan oleh Nor Aini dan Taman (2012), dengan hasil penelitian yang menunjukkan bahwa kemandirian belajar dan lingkungan belajar mempunyai pengaruh yang signifikan terhadap prestasi belajar siswa.

\section{Pengaruh Gaya Belajar Pada Hasil Belajar}

Berdasarkan hasil penelitian mengenai pengaruh gaya belajar pada hasil belajar menunjukkan bahwa gaya belajar berpengaruh signifikan positif pada hasil belajar. Hal ini ditunjukkan melalui hasil persamaan regresi linier berganda diperoleh nilai t-hitung pada gaya belajar (X2) sebesar dengan tingkat signifikan 3,255 dengan tingkat signifikan kurang dari 5\% yaitu 0,002 , artinya semakin tingggi gaya belajar maka semakin tinggi hasil belajar siswa.Koefisien regresi pada variabel gaya belajar sebesar 0,458 menunjukkan bahwa gaya belajar memiliki pola hubungan yang searah dengan hasil belajar yaitu semakin tinggi gaya belajar maka semakin tinggi hasil belajar siswa.

Hasil temuan tersebut sesuai kajian teori dalam Deporter dan Hernacki (2001) mengemukakan bahwa individu dalam belajar memiliki berbagai macam cara, ada yang belajar dengan caragaya auditorial, ada yang dengan gaya belajar 
visual dan gaya belajar kinestetik. Dalam penelitian ini gaya belajar dibatasi pada gaya belajar kinestetik.

Menurut Gunawan (2004) gaya belajar kinestetik adalah gaya belajar siswa yang melalui gerakan. Siswa yang belajar dengan gaya belajar kinestetik sangat suka belajar dengan menyentuh atau memanipulasi objek atau peralatan. Dryden dan Jeannette (2002) menyatakan gaya belajar kinestetik adalah belajar yang melalui aktivitas fisik dan keterlibatan langsung. Proses pembelajaran yang tidak bisa berdiam diri karena ingin melibatkan fisiknya untuk terlibat langsung. Siswa yang memiliki gaya belajar kinestetik selalu ingin memperagakan secara langsung tanpa membacainstruksi yang disediakan. Siswa suka menangani, bergerak, menyentuh dan merasakan atau mengalami sendiri.

Begitu juga Rose dan Nicholl (2002) menyatakan bahwa gaya belajar kinestetik adalah gaya belajar yang cenderung mudah menerima dan mengolah informasi melalui serangkaian aktivitas yang menggerakkan sebagian/seluruh anggota tubuh dan mempraktekkan hal-hal yang dipelajari.

Selain berdasarkan kajian teori, hasil penelitian ini juga didukung oleh kajian empirik yaitu dari penelitian yang dilakukan oleh Bisri dan Pudjo (2012) dengan hasil penelitian yang menyatakan bahwa terdapat hubungan positif dan signifikan antara kemandirian dan gaya belajar kinestetik dengan hasil belajar siswa baik secara parsial maupun bersama-sama. Selain itu penelitian Halim (2012) yang menyatakan bahwa strategi pembelajaran dan gaya belajar mempunyai pengaruh yang signifikan terhadap hasil belajar siswa.

\section{Pengaruh Lingkungan Belajar Pada Hasil Belajar}

Berdasarkan hasil penelitian mengenai pengaruh lingkungan belajar pada hasil belajar menunjukkan bahwa lingkungan belajar berpengaruh signifikan positif pada hasil belajar. Hal ini ditunjukkan melalui hasil persamaan regresi linier berganda diperoleh nilai t-hitung pada lingkungan belajar (X3) sebesar dengan tingkat signifikan 2,200 dengan tingkat signifikan kurang dari 5\% yaitu 0,030, artinya semakin tingggi lingkungan belajar maka semakin tinggi hasil belajar siswa. Koefisien regresi pada variabel lingkungan belajar sebesar 0,315 menunjukkan bahwa lingkungan belajar memiliki pola hubungan yang searah dengan hasil belajar yaitu semakin tinggi lingkungan belajar maka semakin tinggi hasil belajar siswa.

Hasil penelitian ini sesuai dengan teori yang dinyatakan oleh Tirtaraharja (2005) menyatakan bahwa sepanjang hidupnya manusia selalu dipengaruhi oleh tiga lingkungan pendidikan yaitu lingkungan keluarga, sekolah dan masyarakat. Dalam penelitian ini lingkungan dibatasi pada lingkungan sekolah. Sesuai dengan batasan tersebut menurut Slameto (2010) siswa yang belajar akan menerima pengaruh dari lingkungan keluarga, lingkungan sekolah dan lingkungan masyarakat.

Dalyono juga menyatakan bahwa (2009), Sekolah merupakan satu faktor yang turut mempengaruhi pertumbuhan dan perkembangan anak terutama untuk kecerdasannya, keadaan sekolah mempengaruhi tingkat keberhasilan belajar. Sekolah dapat mengembangkan dan meningkatkan pola pikir anak karena di sekolah mereka dapat belajar bermacam-macam ilmu pengetahuan. Sedangkan Suwarno (2006) mendefinisikan sekolah sebagai lembaga pendidikan yang secara resmi menyelenggarakan kegiatan pembelajaran secara sistematis, berencana, 
sengaja dan terarah yang dilakukan oleh pendidik yang profesional dengan program yang dituangkan kedalam kurikulum tertentu mulai dari taman kanak kanak sampai perguruan negeri. Menurut Hamalik (2005) "Sekolah adalah suatu lembaga yang memberikan pengajaran kepada murid-muridnya". Sekolah dapat mengembangkan dan meningkatkan pola pikir anak karena disekolah mereka dapat belajar bermacam-macam ilmu pengetahuan.

Selain berdasarkan kajian teori, hasil penelitian ini juga didukung kajian empirik dari penelitian terdahulu yaitu penelitian Wahyuningsih dan Djazari (2013) yang menunjukkan bahwa terdapat hubungan positif yang signifikan antara lingkungan sekolah dengan prestasi belajar akuntansi siswa.

\section{Pengaruh Kemandirian, Gaya Belajar dan Lingkungan Belajar Pada Hasil Belajar}

Hasil penelitian menunjukkan bahwa kemandirian, gaya belajar dan lingkungan belajar berpengaruh pada hasil belajar siswa Kelas X Akuntansi SMK PGRI 3 Sidoarjo, baik secara simultan atau bersama--sama. Hal ini dapat dilihat dari hasil uji $\mathrm{F}$ diperoleh $\mathrm{F}$-hitung sebesar 31,940 dengan nilai signifikan $\mathrm{p}=$ 0,000 lebih kecil dari 5\%, yang artinya kemandirian (X1), gaya belajar (X2) dan lingkungan belajar (X3) secara simultan berpengaruh signifikan pada hasil belajar (Y)

Menurut Tirtaraharja dan La Sulo (2005), “ Siswa yang mandiri akan menyadari bahwa hasil belajar yang tinggi memerlukan kerja keras dan usaha yang lebih didorong oleh kemauan sendiri, pilihan sendiri, dan tanggung jawab sendiri dari pembelajar". Dengan kemandirian belajar, siswa akan belajar menguasai materi pelajaran dengan usaha sendiri tanpa adanya guru atau disuruh orang tua, sehingga siswa akan cenderung positif dan aktif dalam belajar, yang berarti dapat memberikan pengaruh terhadap hasil belajar.Kemandirian belajar siswa akan mendorong seseorang tidak mudah tergantung dengan orang lain dalam mempelajari dan menyelesaikan mata pelajaran akuntansi, berusaha untuk mencoba dan memecahkan masalah yang berhubungan dengan proses belajarnya tanpa menggantungkan diri pada orang lain.

Sikap mandiri ini dapat terbentuk karena adanya proses dan tahapan yang perlu dijalani siswa. Dengan sikap mandiri ini siswa akan terus berusaha mengatasi hambatan dalam belajarnya, selain itu juga tidak mudah menyerah, dan bertanggung jawab terhadap hasil belajarnya khususnya hasil belajar akuntansi. Dalam pembelajaran Akuntansi secara umum siswa SMK lebih cenderung atau dominan melakukan aktivitas belajar dengan kegiatan praktik, dengan kata lain lebih banyak menggunakan gaya belajar kinestetik dalam kegiatan belajar dikelas.

Menurut Deporter dan Hernacki (2001), gaya belajar kinestetik merupakan gaya belajar yang mengandalkan fisik dalam proses pembelajaran. Menurut Gunawan (2004) gaya belajar kinestetik adalah gaya belajar siswa yang melalui gerakan. Siswa yang belajar dengan gaya belajar kinestetik sangat suka belajar dengan menyentuh atau memanipulasi objek atau peralatan. Dryden dan Jeannette (2002) menyatakan gaya belajar kinestetik adalah belajar yang melalui aktivitas fisik dan keterlibatan langsung.

Proses pembelajaran yang tidak bisa berdiam diri karena ingin melibatkan fisiknya untuk terlibat langsung. Siswa yang memiliki gaya belajar kinestetik selalu ingin memperagakan secara langsung tanpa membaca instruksi yang 
disediakan. Siswa suka menangani, bergerak, menyentuh dan merasakan atau mengalami sendiri. Begitu juga Rose dan Nicholl (2002) menyatakan bahwa gaya belajar kinestetik adalah gaya belajar yang cenderung mudah menerima dan mengolah informasi melalui serangkaian aktivitas yang menggerakkan sebagian/seluruh anggota tubuh dan mempraktekkan hal-hal yang dipelajari.

Sekolah adalah tempat belajar bagi siswa dan teman-temannya untuk menerima ilmu pengetahuan dari gurunya dengan tujuan agar menjadi warga negara yang cerdas, terampil, dan mempunyai tingkah laku yang baik. Lingkungan sekolah memegang peranan penting bagi perkembangan belajar siswanya. Lingkungan sekolah meliputi lingkungan fisik seperti sarana dan prasarana, sumber belajar dan mediabelajar. Lingkungan sekolah juga menyangkut lingkungan akademis yaitu suasana dan pelaksanaan kegiatan belajar yang memadai. Hal ini sesuai dengan pendapat Dalyono (2009) yang menyatakan bahwa keadaan sekolah tempat belajar seperti kualitas guru, metode mengajarnya, kesesuaian kurikulum dengan kemampuan anak, keadaan fasilitas/perlengkapan sekolah, keadaan ruangan, jumlah murid per kelas, pelaksanaan tata tertib sekolah, dan sebagainya, semua ini turut mempengaruhi keberhasilan belajar

Selain didukung oleh kajian teori, Hasil penelitian ini juga didukung oleh penelitian terahulu yaitu Sagoro (2012) yang menunjukkan bahwa kemandirian belajar, metode pembelajaran dan lingkungan belajar mempengaruhi prestasi belajar akuntansi siswa. Begitu juga penelitian yang dilakukan oleh Bisri dan Pudjo (2012) dengan hasil penelitian yang menyatakan bahwa kemandirian dan gaya belajar kinestetik mempengaruhi hasil belajar siswa baik secara parsial maupun bersama-sama.hasil penelitian ini juga semakain diperkuat oleh penelitian Wahyuningsih dan Moh. Djazari (2013) yang menunjukkan bahwa lingkungan sekolah mempengaruhi hasil belajar siswa secara signifikan.

\section{KESIMPULAN}

Berdasarkan hasil analisis regresi linier berganda, maka simpulan yang dapat diambil adalah sebagai berikut : (1) Pengaruh kemandirian belajar signifikan pada hasil belajar akuntansi siswa kelas X Akuntansi SMK PGRI 3 Sidoarjo, hal ini ditunjukkan dari hasil uji t diperoleh t-hitung $=4,186$ dengan tingkat signifikan $0,000>0,05$. Semakin baik kemandirian belajar pada diri setiap siswa maka akan semakin baik hasil belajar siswa, namun apabila semakin rendah kemandirian belajar siswa maka akan semakin buruk hasil belajar siswa; (2) Pengaruh gaya belajar signifikan pada hasil belajar akuntansi siswa kelas X Akuntansi SMK PGRI 3 Sidoarjo, hal ini ditunjukkan dari hasil uji t diperoleh thitung $=3,255$ dengan tingkat signifikan 0,002 >0,05. Semakin baik gaya belajar pada diri setiap siswa maka akan semakin baik hasil belajar siswa, namun apabila semakin rendah gaya belajar siswa maka akan semakin buruk hasil belajar siswa; (3) Pengaruh lingkungan belajar signifikan pada hasil belajar akuntansi siswa kelas X Akuntansi SMK PGRI 3 Sidoarjo, hal ini ditunjukkan dari hasil uji t diperoleh t-hitung $=2,200$ dengan tingkat $\mathrm{t}$ signifikan $0,030>0,05$. Semakin baik lingkungan belajar yang diterima setiap siswa maka akan semakin baik hasil belajar siswa, namun apabila semakin rendah lingkungan belajar yang diterima siswa maka akan semakin buruk hasil belajar siswa; (4) Pengaruh kemandirian belajar, gaya belajar dan lingkungan belajar signifikan pada hasil belajar akuntansi 
siswa kelas X Akuntansi SMK PGRI 3 Sidoarjo sebesar 48,2\%. Hal ini berarti hasil belajar siswa dipengaruhi oleh kemandirian belajar, gaya belajar dan lingkungan belajar sebesar 48,2\%, sedangkan sisanya 51,8\% dipengaruhi oleh faktor-faktor lain yang tidak diteliti

\section{DAFTAR PUSTAKA}

Bisri M, Muh Hasan dan Pudjo Suharso. 2012. Pengaruh Kemandirian dan Gaya Belajar Kinestetik terhadap HasilBelajar pada Siswa kelas XI IPS SMAN Ambulu Mata Pelajaran Akuntansi pada Standar Kompetensi Siklus Akuntansi Perusahaan Jasa Semester Genap Tahun Ajaran 2012/ 201. Jurnal Pendidikan. Vol.24 No.1. pp.38-47

Dalyono, 2009. Psikologi pendidikan. Jakarta : Rineka Cipta

Deporter, Bobbi dan Hernacki, Mike. 2001. Quantum Learning. Bandung : Kaifa

Dryden, Gordon dan Jeannette Vos. 2002. Revolusi Cara Belajar. Bandung Kaifa

Gunawan, Adi. 2004. Genius Learning Strategy : Petunjuk Proses Mengajar.Jakarta: PT. Gramedia Pustaka Utama.

Halim, Abdul. 2012. Pengaruh Strategi Pembelajaran dan Gaya Belajar Terhadap Hasil Belajar Fisika Siswa SMP N 2 Secanggang Kabupaten Langkat. Jurnal Tabularasa, Vol.9 No.2.pp.32-56

Hamalik, Oemar. 2005. Kurikulum dan Pembelajaran. Jakarta: Bumi Aksara.

Hidayati, kana dan Listyani Endang. 2010. Pengembangan Instrumen Kemandirian belajar mahasiswa. Jurnal Penelitian dan Evaluasi Pendidikan. Vol.14 No.1.pp.23-31

Mujiman, Haris. 2007. Manajemen Pelatihan Berbasis Belajar Mandiri. Yogyakarta : Mitra Cendekia

Nor Aini, Pratistya dan Taman, Abdullah. 2012. Pengaruh Kemandirian Belajar dan Lingkungan Belajar Siswa Terhadap Prestasi Belajar Akuntansi Siswa Kelas XI IPS SMA Negeri 1 Sewon Bantul Tahun Ajaran 2010/2011.Jurnal Pendidikan Vol.9 No.10.pp.48-65

Rose, Colin dan Malcolm J. Nicholl. 2002. Accelerated Learning. Bandung: Nuansa.

Sagoro Agung .2012. Pengaruh Kemandirian Belajar, Metode Pembelajaran dan Lingkungan Belajar Terhadap Prestasi Belajar Akuntansi Siswa Kelas X Program Keahlian Akuntansi SMK Muhammadiyah 1 Jatinom Klaten Tahun Ajaran 2011/2012. Jurnal Kajian Pendidikan Akuntansi Indonesia.Vol.5.No.3.pp.67-77

Slameto. 2010. Belajar dan Faktor Faktor yang Mempengaruhi. Jakarta : Rineka Cipta

Suwarno, Wiji. 2006. Dasar Dasar Ilmu Pendidikan. Jogjakarta : Ar Ruzz Media. Tirtahardja, Umar dan S.L La Sulo. 2005. Peran Disiplin Pada Perilaku dan Prestasi Siswa. Jakarta : Grasindo.

Wahyuningsih, Sri dan Moh. Djazari. 2013. "Pengaruh Lingkungan Sekolah dan Kebiasaan Belajar Terhadap Prestasi Belajar Akuntansi Siswa Kelas XI IPS SMA Negeri 1 Srandakan”. Jurnal Ekonomi Bisnis Vol.2 No.3. pp.37-49 